\title{
The Impact of Customer Relationship Management on Customer Loyalty via the Mediating Role of Customer Satisfaction: An Empirical Study on Private Kuwaiti Fitness Gyms
}

\author{
Ra'ed MASA'DEH ${ }^{1}$, Hassan Khalid HAYAT ${ }^{2}$ and Hani AL-DMOUR ${ }^{3}$ \\ ${ }^{1}$ Professor, Management Information Systems Department, School of Business, The University of \\ Jordan, Amman, Jordan \\ ${ }^{2}$ MBA Graduate, Department of Marketing, School of Business, The University of Jordan, Amman, \\ Jordan \\ ${ }^{3}$ Professor, Department of Marketing, School of Business, The University of Jordan, Amman, Jordan
}

Correspondence should be addressed to: Ra'ed MASA'DEH; r.masadeh@ju.edu.jo

Received date:1 October 2019; Accepted date:20 November 2019; Published date:30 December 2019

Academic Editor: Maher Toukabri

Copyright (C) 2019. Ra'ed MASA'DEH, Hassan Khalid HAYAT and Hani AL-DMOUR. Distributed under Creative Commons CC-BY 4.0

\begin{abstract}
The existing research paper was built based on an existing literature from previous researchers and articles and done in a different context (i.e. industry and country). Further, this research contributes to enabling others to understand more between customer relationship management, customer satisfaction and customer loyalty in Kuwaiti private gyms since limited efforts were undertaken to examine this topic in this particular sector. Traditionally, researchers have focused on studying the deal relationship between customer relationship management and customer loyalty through customer satisfaction as a mediating variable. Thus, this research went a step further by not only studying these variables but also by adding an integrated marketing communication as a new variable in customer relationship management practices with also a new mediating variable which is customer satisfaction. The current research comes up with insightful findings and recommendations.
\end{abstract}

Keywords: Customer Relationship Management, Customer Loyalty, Customer Satisfaction, Kuwaiti Private Gyms.

Cite this Article as: Ra'ed MASA'DEH, Hassan Khalid HAYAT and Hani AL-DMOUR (2019)," The Impact of Customer Relationship Management on Customer Loyalty via the Mediating Role of Customer Satisfaction: An Empirical Study on Private Kuwaiti Fitness Gyms ", IBIMA Business Review, Vol. 2019 (2019), Article ID 815930, DOI: $10.5171 / 2019.815930$ 


\section{Introduction}

Developed and developing countries around the world use modern technology, globalization and economic situation in the world to affect their sectors and the country itself locally and globally. They pay a lot of money and resources for researchers to develop more and more. However, Kuwait has not yet developed its sectors and industries such as sports industry through health centers, and lacks research in this sector. This research is important because the results of this study may aid managers of health centers to maintain standards of sports industry in Kuwait, collect, analyze and summarize information about the main problem of joining, not joining and reaching customers loyalty. Therefore, it is about knowing the specific problems that face customers in their decisions of entering these centers and the solutions. To those who are interested in Kuwait people health as well as the managers of healthy centers, the results of this study will provide them with the full understanding of the customers inside the centers and outside to get their satisfaction and loyalty and to know if there are any problems to be solved. The focusing would be in the customer relationship management and its impact upon customer loyalty.

Previous researchers have explored the positive relationship between customer relationship management and customer loyalty (Ashour, 2006; Alshurideh et al., 2012; Malik, 2015; Alananzeh et al., 2018), and the importance of customer relationship management to gain customers (Bashir, 2017). The development of technology made new challenges in the marketplace and the business itself (Piercy \& Rich, 2009). According to the observations of fitness gyms in Kuwait City and the intervening through the telephone with some owners which are: Ibrahim Hayat of Professionals gym in Hawally, Jamal Hayat of the Professionals gym in Maidan Hawally, Mishaal Al-Turki and Bashar Ramadan of Hayat Center in Hawally and Faisal Ashkanani of Muscles Factory in AlShaab
Al-Bahry Area (2017), the reasons of choosing the fitness gyms, which is a part of sport sector as a population, relates to the currently facing of challenges between brand competitors and new competitors in the market. Also, the high switching of customers from one fitness gym to another and the misunderstanding of customers and their needs. The purpose of this study is to find reasons, solutions, impacts, factors affecting customer loyalty to health gyms. The study also aims to develop the sports sector in Kuwait. This study will try to answer the following questions: Do the 10 chosen fitness gyms in Kuwait, Kuwait City have adopted CRM approach as a modern marketing technique? Do CRM practices have an impact on customer loyalty in health centers in Kuwait? Does customer satisfaction play a mediation factor on the relationship between CRM and Customer Loyalty in health centers in Kuwait? Does customer satisfaction play a mediation factor on the relationship between CRM and Customer Loyalty in health centers in Kuwait? Do all of the variables in the framework (CRM, and customer satisfaction) affect customer loyalty in health centers in Kuwait?

This study aims to examine the impact of customer relationship management to reach customer loyalty, through customer satisfaction as a mediation variable of health centers in Kuwait. The rest of the paper is organized as follows: Section 2 describes the research methodology, including the research theoretical framework, research operational definition, the research hypotheses, the research population and sampling, sample size, data collection methods and analysis, and questionnaire development/scale of measurement; Section 3 presents the data analysis and research findings; finally, Section 4 concludes the research discussion and conclusions.

\section{Research Methodology}

This paper will present framework model, research hypotheses, operational definitions of variables; methods used in 
the data collection and applied measurements.

\section{Research Theoretical Framework}

Based on previous empirical research, a conceptual framework has been developed to guide this study as can:

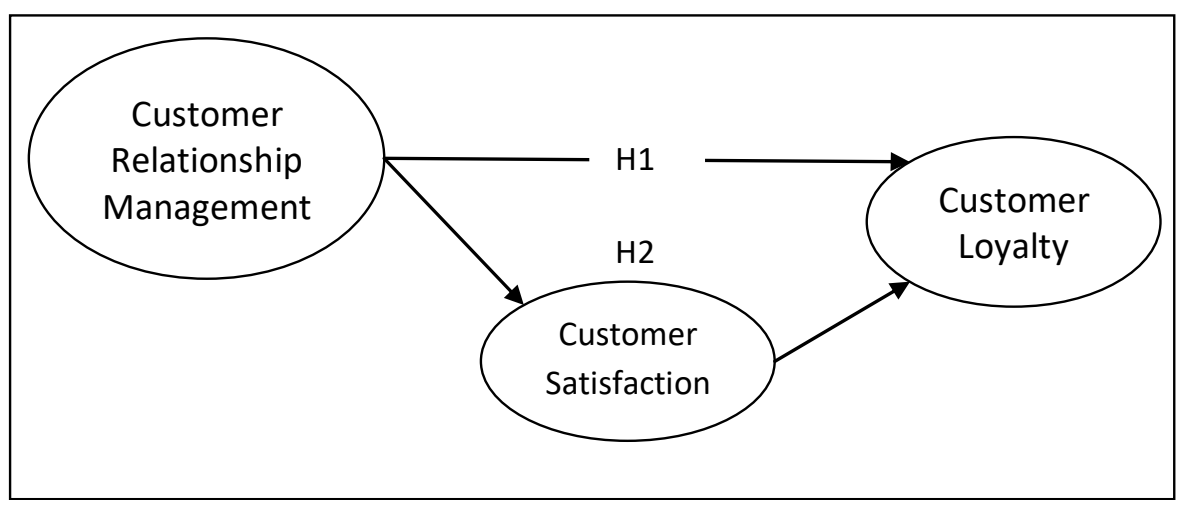

Figure 1: A Conceptual Model

\section{Operational Definition}

Independent variable: Customer Relationship Management which previous studies have conceptualized as a comprehensive tool to build relationships with customers (Rust et al., 2012), the new concept means domination of marketing over public relations (Thorson \& Moore, 1996) and the firm's attempt to inform, persuade and remind customers directly or indirectly about the products and brands they sell (Kotler \& Keller, 2016). The dimensions are Integrated Marketing Communication, Communication, Relational Bonds, and Trust.

Mediation variable: Customer Satisfaction which previous studies have conceptualized as how satisfied the customers are with products and services from the firm (Geyskens et al., 1996), the higher level of expectation which will lead to loyalty (Zins, 2001) and the evaluation of the company's performance with customers. The dimension here is Customer Satisfaction.

Dependent variable: Customer Loyalty which previous studies have conceptualized as divided into Attitudinal which means a positive word of mouth and has been a major study of marketing researchers (Christodoulides \& Michealidou, 2011; Mustafa, 2011), and Behavioral which is a deeply held commitment to re-buy the product or service in the future (Oliver, 1997). The dimensions are Attitudinal and Behavioral Loyalty.

\section{Research Hypothesis}

Based upon the conceptual framework of the impact of Customer Relationship Management upon Customer Loyalty through Customer Satisfaction as a mediation variable, here are the research alternative and null hypotheses:

- Alternative hypothesis 1: There is a significant relationship between customer relationship management and customer loyalty.

- Null hypothesis 1: There is no significant relationship between customer relationship management and customer loyalty.

- Alternative hypothesis 2: Customer satisfaction has significant effect as a mediating factor on the relationship between customer relationship management and customer loyalty. 
- Null hypothesis 2: Customer satisfaction has no significant effect as mediating factor on the relationship between customer relationship management and customer loyalty.

\section{Research Population and Sampling}

Kuwait is a small country with high resources such as Financial and technological and if these resources were used well, the country would be developed better. Kuwait population continued growth and reached 4million people: Kuwaitis are 1.3 million and a 2.7 million are foreigners (Cia World Factbook, 2017). This study is about the impact of customer relationship management upon customer loyalty, and the role of customer satisfaction as a mediating factor of private Kuwaiti fitness gyms. The population of the current study was the participants of the private fitness gyms in Kuwait, Kuwait City.

The sampling of this study was the best 10 fitness gyms in Kuwait, Kuwait City based on the most popular, famous, brand name and numbers of customers according to the observations of the fitness gyms and customers themselves: Oxygen, Platinum, Professionals, Golds and Flex for men, The Corniche, Palms and Crown Plaza for mixed fitness gyms, Flex and Fitness First for the women.

\section{Sample Size}

According to Sekaran \& Bougie (2016), the sample size for any research should be between 50 and 500. According to Tabachnick \& Fidell (2001), a number of 300 responses are good to any study. According to Hill \& Alexander (2006), a sample size of at least 200 to 500 is sufficient for data analysis. The sample size of this study considered to be 400 Kuwaitis and foreigners' responses from the chosen fitness centers in Kuwait City, Kuwait. The sampling unit is individuals because they are only the customers. According to Sekaran \& Bougie (2016), the nonprobability sampling is used when each element in the population does not have the same chance to be a part of the sample. The sampling method in this study is a nonprobability and its technique is convenience sampling which means to give the questionnaire to any available person.

\section{Data Collection Methods and Analysis}

This study is a quantitative research, which used a questionnaire survey to verify the conceptual framework and hypotheses. The questionnaires were distributed by hand only to customers in 10 fitness gyms in Kuwait City, Kuwait. To measure the questionnaire items, the study used a fivepoint Likert scale from one to five, rating from strongly disagree to strongly agree. The time horizon of this study is CrossSectional which means at this time and the SPSS was used to analyze the data.

\section{Questionnaire Development/Scale of Measurement}

The first table mentions the independent variable which is customer relationship management, the second table mentions the mediating variable which is customer satisfaction and the third table mentions the dependent variable which is customer loyalty and all of them including the dimensions and their elements: 
Table 1: Independent Variable, Dimensions, Elements and Previous Studies that were Beneficial for Developing the Measuring Instruments

\begin{tabular}{|c|c|c|c|}
\hline $\begin{array}{c}\text { Independent } \\
\text { Variable }\end{array}$ & Dimensions & Elements & Resources from Previous Studies \\
\hline \multirow{15}{*}{$\begin{array}{l}\text { 1-Customer } \\
\text { Relationship } \\
\text { Management: }\end{array}$} & \multirow{6}{*}{$\begin{array}{l}\text { Integrated } \\
\text { Marketing } \\
\text { Communication }\end{array}$} & Promotions & \multirow{15}{*}{$\begin{array}{l}\text { Thorson \& Moore, 1996; Too et al., } \\
\text { 2001; Bose, 2002; Schultz, 2003; } \\
\text { Schultz \& Schultz, 2003; Boulding et } \\
\text { al., 2005; Kerr et al., 2008; Finnegan\& } \\
\text { Currie, 2010; Fathi et al., 2012; } \\
\text { Kocoglu \& Kirmaci, 2012; Rust et al., } \\
\text { 2012; Chikweche \& Fletcher, 2013; } \\
\text { Long et al., 2013; Mohite et al., 2013; } \\
\text { Amir et al., 2014; Fozia \& Shiamwama, } \\
\text { 2014; Nazir et al., 2014; Rehman et al., } \\
\text { 2014; Malik, 2015; Suwono \& } \\
\text { Sihombing, 2016; Bashir, 2017; Rahim, } \\
\text { 2017. }\end{array}$} \\
\hline & & Sales & \\
\hline & & Advertisements & \\
\hline & & Sponsorships & \\
\hline & & Packaging & \\
\hline & & $\begin{array}{l}\text { E-commerce } \\
\text { events }\end{array}$ & \\
\hline & \multirow[t]{3}{*}{ Communication } & Email messages & \\
\hline & & Phone calls & \\
\hline & & Text messages & \\
\hline & \multirow[t]{3}{*}{ Relational Bonds } & Social Bonds & \\
\hline & & $\begin{array}{l}\text { Special } \\
\text { Treatment }\end{array}$ & \\
\hline & & Financial Bonds & \\
\hline & \multirow[t]{3}{*}{ Trust } & $\begin{array}{l}\text { Trust on the } \\
\text { center's } \\
\text { employees }\end{array}$ & \\
\hline & & Honesty & \\
\hline & & Overall Trust & \\
\hline
\end{tabular}

The previous table showed the independent variable which is customer relationship management. It has four dimensions which are: integrated marketing communications, communications, relational bonds and trust. The first dimension has six elements: promotions, sales, advertisement, sponsorships, packaging and e-commerce events. The second dimension has three elements: email messages, phone calls and text messages. The third dimension has three elements: social bonds, special treatment and financial bonds. The fourth dimension has three dimensions: trust in the center's employees, honesty and overall trust. 
Table 2: Mediating Variables, Dimensions, Elements and Previous Studies those were beneficial for Developing the Measuring Instruments

\begin{tabular}{|c|c|c|c|}
\hline $\begin{array}{l}\text { Mediating } \\
\text { Variables }\end{array}$ & Dimensions & Elements & Previous Studies \\
\hline \multirow[t]{2}{*}{$\begin{array}{l}\text { Customer } \\
\text { Satisfaction }\end{array}$} & \multirow[t]{2}{*}{$\begin{array}{l}\text { Customer } \\
\text { Satisfaction }\end{array}$} & Expectation & \multirow{2}{*}{$\begin{array}{l}\text { Anderson \& Lehmann, 1994; } \\
\text { Geyskens, Steenkamp, Scheer \& } \\
\text { Cumar, 1996; Choi \& Chu, 2000; } \\
\text { Fisher, 2001; Zins, 2001; Chan et } \\
\text { al., 2003; Roberts et al., 2003; } \\
\text { Aydin et al., 2005; Javadein, } \\
\text { Khanlari \& Estiri, 2008; Kotler \& } \\
\text { Killer, 2016. }\end{array}$} \\
\hline & & Overall Satisfaction & \\
\hline
\end{tabular}

The previous table showed the mediating variable which is customer satisfaction, and it has one dimension of customer satisfaction with two elements which are expectation and overall satisfaction.

Table 3: Dependent Variable, Dimensions, Element and Previous Studies that were Beneficial for Developing the Measuring Instruments

\begin{tabular}{|l|l|l|l|}
\hline $\begin{array}{c}\text { Dependent } \\
\text { Variable }\end{array}$ & \multicolumn{1}{|c|}{ Dimensions } & \multicolumn{1}{|c|}{ Elements } & \multicolumn{1}{|c|}{ Previous Studies } \\
\hline 1-Customer Loyalty & $\begin{array}{l}\text { Attitudinal } \\
\text { Loyalty }\end{array}$ & $\begin{array}{l}\text { Positive Word of } \\
\text { Mouth }\end{array}$ & $\begin{array}{l}\text { Oliver, 1997; Oliver et al., 1997; } \\
\text { Huffmire, 2001; Christodoulides } \\
\text { \& Michealidou, 2011; Ltifi \& } \\
\text { Jamel-Eddine, 2012; Javadein et } \\
\text { al., 2008; Lovelock \& Wirtz, 2017. }\end{array}$ \\
\cline { 2 - 4 } & $\begin{array}{l}\text { Behavioral } \\
\text { Loyalty }\end{array}$ & $\begin{array}{l}\text { Rejoin the } \\
\text { center }\end{array}$ & \\
\hline
\end{tabular}

The previous table showed the dependent variable which is customer loyalty. It has dimensions of attitudinal and behavioral loyalty. Attitudinal loyalty has one element and it is the positive word of mouth. Behavioral loyalty has one element and it is rejoining the center.

\section{Data Analysis \& Research Findings}

Research of validity and reliability, data presentation and description, and hypotheses testing will be discussed next.

\section{Research Validity and Reliability}

The questionnaire had been presented to experts, specialized and professional people in order to know their views, ideas, and appropriateness of all the questions to the research objectives to examine the validity of this study instrument. They suggested some adjustments and corrections to be more improved. Their recommendations were very helpful to the approved majority of the questionnaire.

Reliability of the chosen instruments is required to test stability and consistency. Consistency shows how the selected items work together as a set. Reliability which shows how well the items in a set are positively correlated to each other is the Cronbach's alpha coefficient used, and the closer Cronbach's alpha is to number one means the higher and greater the reliability of internal consistency and instrument (Sekaran \& Bougie, 2016). For this study, reliability was measured by the internal consistency. Cronbach's alpha is the most popular and chosen method in behavioral studies. The minimum accepted level of this method should be 0.60 (Hair et al., 2010). 
Table 4: Reliability Coefficients of Study Variables

\begin{tabular}{|l|c|c|}
\hline \multicolumn{1}{|c|}{ Variables } & Cronbach's Alpha & No. of items \\
\hline $\begin{array}{c}\text { Customer Relationship } \\
\text { Management }\end{array}$ & 0.799 & 16 \\
\hline $\begin{array}{l}\text { Integrated Marketing } \\
\text { Communications }\end{array}$ & 0.798 & 6 \\
\hline Communications & 0.796 & 3 \\
\hline Relational Bonds & 0.803 & 4 \\
\hline Trust & 0.799 & 8 \\
\hline Customer Satisfaction & 0.800 & 8 \\
\hline Overall Satisfaction & 0.800 & 8 \\
\hline Customer Loyalty & 0.797 & 4 \\
\hline Attitudinal Loyalty & 0.797 & 4 \\
\hline Behavioral Loyalty & 0.796 & 8 \\
\hline
\end{tabular}

For this research, the values of Cronbach's alpha method were calculated to identify the internal reliability. The results showed in table 4 that the reliability of the research variables is higher than 0.60 as proposed by Hair et al. (2010). This means that the research instrument has a high degree of reliability.

\section{Data Presentation}

This section shows percentages and frequency distribution applied to describe data related to respondents' characteristics such as age, gender, occupation, gym name and since when they are members of the gym. The demographic factors of respondents are required to develop customer relationship management in order to reach customer loyalty (Clemes et al., 2009). Table 5 shows that the majority of the respondents in this sample were 275 males, which means the percentage of $68.8 \%$ and 125 females which mean $31.2 \%$.

Table 5: Gender Type

\begin{tabular}{|l|c|c|c|}
\hline \multicolumn{2}{|c|}{} & Frequency & Percent \\
\hline \multirow{3}{*}{ Valid } & Male & 275 & 68.8 \\
\cline { 2 - 4 } & Female & 125 & 31.2 \\
\cline { 2 - 4 } & Total & 400 & 100.0 \\
\hline
\end{tabular}

Table 6 shows that the higher majority of respondents ages in the sample are a total of 140 respondents in this sample and were between the age of 21 to 25 with a percent of 35\%, and the lowest majority of respondents ages are a total of 27 respondents and were between the age of 36 to 40 with a percent of $6.8 \%$. 
Table 6: Ages

\begin{tabular}{|c|c|c|c|}
\hline \multicolumn{2}{|c|}{} & Frequency & Percent \\
\hline \multirow{3}{*}{ Valid } & under 20 & 67 & 16.8 \\
\cline { 2 - 4 } & between 21 to 25 & 140 & 35.0 \\
\cline { 2 - 4 } & between 26 to 30 & 93 & 23.3 \\
\cline { 2 - 4 } & between 31 to 35 & 42 & 10.5 \\
\cline { 2 - 4 } & between 36 to 40 & 27 & 6.8 \\
\cline { 2 - 4 } & above 40 & 31 & 7.6 \\
\cline { 2 - 4 } & Total & 400 & 100.0 \\
\hline
\end{tabular}

Table 7 indicates that a majority of respondents in the sample were a total of 185 students with a percent of $46.3 \%$, a total of 209 employees with a percent of $52.2 \%$ and only an unemployed of 6 respondents with a percent of $1.5 \%$.

Table 7: Occupation

\begin{tabular}{|c|c|c|c|}
\hline \multicolumn{2}{|c|}{} & Frequency & Percent \\
\hline \multirow{3}{*}{ Valid } & student & 185 & 46.3 \\
\cline { 2 - 4 } & employee & 209 & 52.2 \\
\cline { 2 - 4 } & unemployed & 6 & 1.5 \\
\cline { 2 - 4 } & Total & 400 & 100.0 \\
\hline
\end{tabular}

Table 8 indicates a majority of respondents in the sample were a total of 40 with a percent of $10.0 \%$ from all the chosen private gyms in Kuwait for men, mixed and women. 
Table 8: Fitness Center Names

\begin{tabular}{|l|l|c|c|}
\hline \multicolumn{2}{|l|}{} & Frequency & Percent \\
\hline Valid & Oxygen for men & 40 & 10.0 \\
\cline { 2 - 4 } & Platinum for men & 40 & 10.0 \\
\cline { 2 - 4 } & Professionals for men & 40 & 10.0 \\
\cline { 2 - 4 } & Gold's for men & 40 & 10.0 \\
\cline { 2 - 4 } & Flex for men & 40 & 10.0 \\
\cline { 2 - 4 } & $\begin{array}{l}\text { The Corniche for mixed } \\
\text { genders }\end{array}$ & 40 & 10.0 \\
\cline { 2 - 4 } & Palms for mixed genders & 40 & 10.0 \\
\cline { 2 - 4 } & $\begin{array}{l}\text { Crown Plaza hotel gym for } \\
\text { mixed genders }\end{array}$ & 40 & 10.0 \\
\cline { 2 - 4 } & Flex for women & 40 & 10.0 \\
\cline { 2 - 4 } & $\begin{array}{l}\text { Fitness First for the } \\
\text { women }\end{array}$ & 40 & 10.0 \\
\cline { 2 - 4 } & Total & 400 & 100.0 \\
\hline
\end{tabular}

Table 9 is the last table in data presentation. It indicates that the highest majority of respondents in the sample were a total of 186 respondents that joined the gym before less between the last five to ten years with a percent of $46.5 \%$, and the lowest majority of respondents were only 5 respondents who joined the gym before more than ten years with a percent of $1.3 \%$.

Table 9: Since when you Joined this Fitness Center

\begin{tabular}{|l|l|c|c|}
\hline \multicolumn{2}{|c|}{} & Frequency & Percent \\
\hline Valid & less than 3 months & 30 & 7.5 \\
\cline { 2 - 4 } & Between 3 to 6 months & 66 & 16.5 \\
\cline { 2 - 4 } & Between 6 to one year & 58 & 14.5 \\
\cline { 2 - 4 } & between one to five years & 55 & 13.7 \\
\cline { 2 - 4 } & between five to ten years & 186 & 46.5 \\
\cline { 2 - 4 } & more than ten years & 5 & 1.3 \\
\cline { 2 - 4 } & Total & 400 & 100.0 \\
\hline
\end{tabular}

\section{Data Descriptive}

The mean and standard deviation were used in this study to describe responses and their attitude toward each question was asked in the questionnaire. Given a scale used in this study of a five-point Likert scale with criteria for determining a classification for every item was based on the next formula: (5-1) / $5=0.80$ which means (highest point - lowest point) / the number of levels used.

Table 10 summarizes the mean and standard deviation levels (high, medium, low) of the independent factor which is

Ra'ed MASA'DEH, Hassan Khalid HAYAT and Hani AL-DMOUR (2019), IBIMA Business Review, DOI: $10.5171 / 2019.815930$ 
customer relationship management, the mediating factor which is and customer satisfaction; and the dependent factor of customer loyalty including all of their variables in this study. It showed that customer relationship management has a medium level, customer satisfaction has a high level, customer satisfaction has a high level and customer loyalty has a low level of standard deviation as an overall.

Table 10: Mean Average Score and Standard Deviation of the Research Variables

\begin{tabular}{|c|c|c|c|}
\hline Variable & Mean & Std. Deviation & $\begin{array}{c}\text { Level of Std. } \\
\text { Deviation }\end{array}$ \\
\hline \multicolumn{4}{|c|}{ Independent Variables } \\
\hline Customer Relation management & 4.388 & 0.734 & Medium \\
\hline Integrated Marketing Communication & 4.407 & 0.723 & Medium \\
\hline Communications & 4.371 & 0.568 & Low \\
\hline Relational Bonds & 4.432 & 1.067 & High \\
\hline Trust & 4.343 & 0.581 & Low \\
\hline \multicolumn{4}{|c|}{ Mediating variables } \\
\hline Customer Satisfaction & 4.355 & 1.282 & High \\
\hline Customer Satisfaction & 4.355 & 1.282 & High \\
\hline \multicolumn{4}{|c|}{ Dependent Variables } \\
\hline Customer Loyalty & 4.425 & 0.570 & Low \\
\hline Attitudinal Loyalty & 4.421 & 0.583 & Low \\
\hline Behavioral Loyalty & 4.429 & 0.557 & Low \\
\hline
\end{tabular}

\section{Hypotheses Testing}

Simple, multiple, stepwise regression and (ANOVA) were sued to test the main hypothesis and were using the linear procedure in SPSS.

\section{Testing the First Alternative Hypothesis}

"There is a significant relationship between customer relationship management and customer loyalty".

Table 11: Results of Regression Analysis for the Effect of Customer Relationship Management Dimensions “I.M.C, Relational Bonds, Trust and Communication” upon Customer Loyalty

\begin{tabular}{|c|c|c|c|c|}
\hline Model & R & R Square & $\begin{array}{c}\text { Adjusted R } \\
\text { Square }\end{array}$ & $\begin{array}{c}\text { Std. Error of the } \\
\text { Estimate }\end{array}$ \\
\hline 1 & $0.790^{\mathrm{a}}$ & 0.625 & 0.621 & 1.83539 \\
\hline
\end{tabular}

a. Predictors: (Constant), trust, Relational bonds, I.M.C, Communications

The correlation coefficient of $\mathrm{R}$ is the statistical method technique that identifies whether and how strongly pairs of the variables are related to each other or not. In this study, the correlation coefficient of $\mathrm{R}$ is 0.790 which means a positive relationship between independent variables and customer loyalty.

The R-square shows the percentage of variation in the dependent variable. In this study, the R square is 0.625 which means a $62.5 \%$ of changeability of customer loyalty

Ra'ed MASA'DEH, Hassan Khalid HAYAT and Hani AL-DMOUR (2019), IBIMA Business Review, DOI: $10.5171 / 2019.815930$ 
is explained by independent variables. The adjusted $\mathrm{R}$ square in this research is 0.625 which is close to $\mathrm{R}$ square value and it is always been less or equal $\mathrm{R}$ square. It means that there will be 0.004 less variance in the model result. Adjusted R square is the goodness of fit measurement.

Table 12: Analysis of Variance for the Effect of the Customer Relationship Management Dimensions “Trust, I.M.C, Relational Bonds and Communications” upon Customer Loyalty

\begin{tabular}{|c|c|c|c|c|c|c|}
\hline Model & $\begin{array}{c}\text { Sum of } \\
\text { Squares }\end{array}$ & df & $\begin{array}{c}\text { Mean } \\
\text { Square }\end{array}$ & $\mathbf{F}$ & Sig. & Result \\
\hline Regression & 2215.764 & 4 & 553.941 & 164.439 & $0.000 \mathrm{~b}$ & \multirow{3}{*}{$\begin{array}{l}\text { Accept the } \\
\text { alternative } \\
\text { hypothesis }\end{array}$} \\
\hline Residual & 1330.626 & 395 & 3.369 & & & \\
\hline Total & 3546.390 & 399 & & & & \\
\hline
\end{tabular}

a. Dependent Variable: customer loyalty

b. Predictors: (Constant), trust, Relational bonds, I.M.C, Communications

The (ANOVA) is to test the main null hypothesis. The statistical significance of variables checked for a value less than 0.05 levels. The F-ratio for this data is 164.439 , which is significant at the level of P less than 0.05. Finally, the researchers should accept the alternative hypothesis.

Table 13: Coefficient for the Effect of Customer Relationship Management Dimensions “Trust, I.M.C, Relational Bonds and Communications" upon Customer Loyalty

\begin{tabular}{|c|c|c|c|c|c|c|}
\hline \multicolumn{7}{|c|}{ Coefficients } \\
\hline \multirow{2}{*}{\multicolumn{2}{|c|}{ Model }} & \multicolumn{2}{|c|}{$\begin{array}{c}\text { Unstandardized } \\
\text { Coefficients }\end{array}$} & \multirow{2}{*}{$\begin{array}{c}\begin{array}{c}\text { Standardized } \\
\text { Coefficients }\end{array} \\
\text { Beta } \\
\end{array}$} & \multirow[t]{2}{*}{$\mathbf{t}$} & \multirow[t]{2}{*}{ Sig. } \\
\hline & & B & Std. Error & & & \\
\hline \multirow[t]{5}{*}{1} & (Constant) & 7.846 & 1.325 & & 5.923 & 0.000 \\
\hline & I.M.C & 0.424 & 0.045 & 0.321 & 9.410 & 0.000 \\
\hline & $\begin{array}{l}\text { Communication } \\
\mathrm{s}\end{array}$ & 1.023 & 0.069 & 0.590 & 14.757 & 0.000 \\
\hline & $\begin{array}{l}\text { Relational } \\
\text { bonds }\end{array}$ & 0.119 & 0.033 & 0.117 & 3.613 & 0.000 \\
\hline & Trust & 0.072 & 0.109 & 0.027 & 0.666 & 0.506 \\
\hline
\end{tabular}

The multiple regression tests finished as shown in table 13 which showed coefficient beta measures the contribution of every variable in the framework model. All of the independent variables are significant with a level of 0.00 but only the variable of Trust is not significant with a level of 0.506 which is more than the significant level of 0.05 .
Stepwise Test for the First Alternative Hypothesis

The movement of one variable from the independent variables, which is trust, is to support the results. A stepwise done on the four independent variables upon customer loyalty. 
Table 14: Stepwise Test-Model Summary for Effective Customer Relationship Management Dimensions “Communications, I.M.C, and Relational Bonds"

\begin{tabular}{|c|c|c|c|c|c|}
\hline \multicolumn{7}{|c|}{ Model Summary } \\
\hline Model & $\mathrm{R}$ & $\mathrm{R}$ & $\begin{array}{c}\text { Adjusted R } \\
\text { Square }\end{array}$ & $\begin{array}{c}\text { Std. Error of } \\
\text { the Estimate }\end{array}$ & Change Statistics \\
\cline { 5 - 6 } & & Square & 0.49. F Change \\
\hline 1 & $0.700^{\mathrm{a}}$ & 0.490 & 0.489 & 2.13098 & 0.000 \\
\hline 2 & $0.782^{\mathrm{b}}$ & 0.612 & 0.610 & 1.86187 & 0.000 \\
\hline 3 & $0.790^{\mathrm{c}}$ & 0.624 & 0.622 & 1.83410 & 0.000 \\
\hline
\end{tabular}

Table 14 showed the $\mathrm{R}$ for the first independent variable alone "communications" was 0.700 and increased to 0.782 when the second parameter "I.M.C" entered the equation, then increased to 0.790 when the third parameter "relational bonds" entered the equation. It also showed that the $\mathrm{R}$ square for the first independent variable alone "communications" was 0.489 and increased to 0.612 when the second parameter "I.M.C" entered the equation, then increased to 0.624 when the third parameter "relational bonds" entered the equation. All of the variables in this table are significant with a level of 0.000 .
The next tables of 15 and 16 showed the significant results in the results of ANOVA test for the three independent variables, which are "communications, I.M.C and relational bonds", which means that the dimension of "trust" is out of the stepwise test model because it has a negative effect on the relationship between customer relationship management and customer loyalty. 
Table 15: Coefficient for the Effect of the Three Dimensions "I.M.C, Relational Bonds and Communications" of Customer Relationship Management upon Customer Loyalty in the Stepwise Test Coefficients ${ }^{\mathrm{a}}$

\begin{tabular}{|c|c|c|c|c|c|c|}
\hline \multicolumn{2}{|c|}{ Model } & \multicolumn{2}{|c|}{$\begin{array}{c}\text { Unstandardized } \\
\text { Coefficients }\end{array}$} & \multirow{2}{*}{$\begin{array}{c}\begin{array}{c}\text { Standardized } \\
\text { Coefficients }\end{array} \\
\text { Beta }\end{array}$} & \multirow[t]{2}{*}{$t$} & \multirow[t]{2}{*}{ Sig. } \\
\hline & & B & Std. Error & & & \\
\hline \multirow[t]{2}{*}{1} & (Constant) & 19.556 & 0.817 & & 23.940 & 0.000 \\
\hline & $\begin{array}{l}\text { Communication } \\
\mathrm{S}\end{array}$ & 1.215 & 0.062 & 0.700 & 19.569 & 0.000 \\
\hline \multirow[t]{3}{*}{2} & (Constant) & 9.035 & 1.183 & & 7.638 & 0.000 \\
\hline & $\begin{array}{l}\text { Communication } \\
\mathrm{s}\end{array}$ & 1.062 & 0.056 & 0.612 & 18.983 & 0.000 \\
\hline & I.M.C & 0.475 & 0.043 & 0.360 & 11.152 & 0.000 \\
\hline \multirow[t]{4}{*}{3} & (Constant) & 8.238 & 1.186 & & 6.946 & 0.000 \\
\hline & $\begin{array}{l}\text { Communication } \\
\mathrm{s}\end{array}$ & 1.051 & 0.055 & 0.606 & 19.043 & 0.000 \\
\hline & I.M.C & 0.431 & 0.044 & 0.326 & 9.846 & 0.000 \\
\hline & $\begin{array}{l}\text { Relational } \\
\text { bonds }\end{array}$ & 0.120 & 0.033 & 0.117 & 3.621 & 0.000 \\
\hline
\end{tabular}

Table 16: Analysis of Variance for the Effect of the Three Dimensions "I.M.C, Relational Bonds and Communications" of Customer Relationship Management upon Customer Loyalty in the Stepwise Test

\begin{tabular}{|c|c|c|c|c|c|c|c|}
\hline \multicolumn{8}{|c|}{ ANOVA $^{a}$} \\
\hline \multicolumn{2}{|c|}{ Model } & $\begin{array}{c}\text { Sum of } \\
\text { Squares }\end{array}$ & df & $\begin{array}{c}\text { Mean } \\
\text { Square }\end{array}$ & $\mathbf{F}$ & Sig. & Sig. \\
\hline \multirow[t]{3}{*}{1} & Regression & 1739.048 & 1 & 1739.048 & $\begin{array}{c}382 . \\
961\end{array}$ & $\begin{array}{c}0.000 \\
b\end{array}$ & \multirow{9}{*}{$\begin{array}{l}\text { Accept the } \\
\text { alternative } \\
\text { hypothesis }\end{array}$} \\
\hline & Residual & 1807.342 & 398 & 4.541 & & & \\
\hline & Total & 3546.390 & 399 & & & & \\
\hline \multirow[t]{3}{*}{2} & Regression & 2170.161 & 2 & 1085.080 & $\begin{array}{l}313 . \\
013\end{array}$ & $\begin{array}{c}0.000 \\
\mathrm{c}\end{array}$ & \\
\hline & Residual & 1376.229 & 397 & 3.467 & & & \\
\hline & Total & 3546.390 & 399 & & & & \\
\hline \multirow[t]{3}{*}{3} & Regression & 2214.271 & 3 & 738.090 & $\begin{array}{l}219 . \\
413\end{array}$ & $\begin{array}{c}0.000 \\
\mathrm{~d}\end{array}$ & \\
\hline & Residual & 1332.119 & 396 & 3.364 & & & \\
\hline & Total & 3546.390 & 399 & & & & \\
\hline \multicolumn{8}{|c|}{ a. Dependent Variable: Customer Loyalty } \\
\hline \multicolumn{8}{|c|}{ b. Predictors: (Constant), Communications } \\
\hline \multicolumn{8}{|c|}{ c. Predictors: (Constant), Communications, I.M.C } \\
\hline \multicolumn{8}{|c|}{ d. Predictors: (Constant), Communications, I.M.C, Relational bonds } \\
\hline
\end{tabular}

Ra'ed MASA'DEH, Hassan Khalid HAYAT and Hani AL-DMOUR (2019), IBIMA Business Review, DOI: $10.5171 / 2019.815930$ 
The above-mentioned outcomes are considered as supportive information for this research specifically for the study model.

\section{Testing the Second Alternative Hypothesis}

"Customer satisfaction has a significant effect as mediating on the relationship between customer relationship management and customer loyalty".
According to the previous mediating hypothesis, the same steps for this second one as a second mediating variable in this study. The next table 17 indicated a R-value of $0.800, \mathrm{R}$ square of 0.640 which means a $64 \%$ with a positive significant value of the chosen variable because they are less than 0.05 . The $\mathrm{R}$ changed from 0.763 to 0.800 which means an increase of $0.37 \%$ and the $\mathrm{R}$ square from 0.582 to 0.640 which means an increase of 0.058 .

Table 17: Model Summary

\begin{tabular}{|c|c|c|c|c|c|}
\hline Model & R & R Square & $\begin{array}{c}\text { Adjusted R } \\
\text { Square }\end{array}$ & $\begin{array}{c}\text { Std. Error of } \\
\text { the Estimate }\end{array}$ & Change Statistics \\
\cline { 4 - 6 } & & 0.640 & 0.638 & 1.79308 & Sig. F Change \\
\hline 1 & $0.800^{\text {a }}$ & 0.640 & 0.000 \\
\hline a. Predictors: (Constant), customer satisfaction, customer relationship management variables \\
\hline
\end{tabular}

According to the next tables 18 and 19 of ANOVA and Coefficient, for the effect of customer relationship management as independent factor and customer satisfaction as mediating factor upon customer loyalty which is the dependent factor, the third alternative hypothesis should be accepted, because of the positive significant level of the chosen variables which is 0.000 for both of them.

Table 18: Analysis of Variance for the Effect of Customer Relationship Management and Customer Satisfaction Variables upon Customer Loyalty

\begin{tabular}{|c|c|c|c|c|c|c|c|}
\hline \multicolumn{2}{|c|}{ Model } & $\begin{array}{c}\text { Sum of } \\
\text { Squares }\end{array}$ & df & $\begin{array}{c}\text { Mean } \\
\text { Square }\end{array}$ & F & Sig. & Results \\
\hline \multirow{2}{*}{1} & Regression & 2269.985 & 2 & 1134.992 & 353.01 \\
& & & & 0.00 & $\begin{array}{c}\text { Accept the } \\
\text { alternative } \\
\text { hypothesis }\end{array}$ \\
\cline { 2 - 8 } & Residual & 1276.405 & 39 & 3.215 & & & \\
\cline { 2 - 8 } & Total & 3546.390 & 39 & & & & \\
\hline
\end{tabular}

Ra'ed MASA'DEH, Hassan Khalid HAYAT and Hani AL-DMOUR (2019), IBIMA Business Review, DOI: $10.5171 / 2019.815930$ 
Table 19: Coefficient for the Effect of Customer Relationship Management and Customer Satisfaction Variables upon Customer Loyalty

\begin{tabular}{|c|c|c|c|c|c|c|}
\hline \multicolumn{7}{|c|}{ Coefficients $^{a}$} \\
\hline \multirow{2}{*}{\multicolumn{2}{|c|}{ Model }} & \multicolumn{2}{|c|}{$\begin{array}{l}\text { Unstandardized } \\
\text { Coefficients }\end{array}$} & \multirow{2}{*}{$\begin{array}{c}\begin{array}{c}\text { Standardized } \\
\text { Coefficients }\end{array} \\
\text { Beta }\end{array}$} & \multirow[t]{2}{*}{$t$} & \multirow[t]{2}{*}{ Sig. } \\
\hline & & B & Std. Error & & & \\
\hline \multirow[t]{3}{*}{1} & (Constant) & 6.754 & 1.107 & & 6.102 & 0.000 \\
\hline & $\begin{array}{c}\text { Customer } \\
\text { Relationship } \\
\text { Management }\end{array}$ & 0.328 & 0.017 & 0.633 & 18.819 & 0.000 \\
\hline & $\begin{array}{l}\text { Customer } \\
\text { satisfaction }\end{array}$ & 0.161 & 0.019 & 0.283 & 8.417 & 0.000 \\
\hline
\end{tabular}

\section{Discussion and Conclusions}

The current research was able to conceptualize how customer relationship management affected customer loyalty with two mediating variables which affected the relationship between customer relationship management and customer loyalty. In this research, the outcomes showed a statistically significant relationship between independent variables factors, which are integrated marketing communication, communications, relational bonds and trust as an overall. Based on the previous outcomes, the results of coefficient beta as in table 13 presented the dimension "trust" as non-significant which is a negative relationship or result. Of course, to support these outcomes a stepwise regression method was done to find out the most effective independent variables on customer loyalty. The results showed the same result that trust has no impact on customer loyalty, and an increase in coefficient of determination in table 14 . This negative result for "trust" variable might be due to not considering this variable as a strategy for the private gyms in Kuwait, unawareness between gym's employees regards the importance of customer trust, and not taking trust as an important predictor in customer loyalty. Also, the research showed an acceptance of the alternative hypothesis and there is a significant relationship between independent variable and customer loyalty as overall.
According to Ashour (2006), Long et al. (2013), Amir et al. (2014), Fozia \& Shiamwama(2014), Malik (2015), Al-Naser (2016), Khawaja (2016), and Bashir (2017), there is a significant positive relationship between customer relationship management practices and customer loyalty and the entire majority of customer relationship management are considered significant predictors. So, all of them supported the first hypothesis in this research which is "there is a significant relationship between customer relationship management and customer loyalty".

The third alternative hypothesis which is "Customer satisfaction has a significant effect on mediating on the relationship between customer relationship management and customer loyalty" showed by statistics results that it is accepted and research such as Long et al. (2013), Nazir et al. (2014), and Rahim (2017) supported this result by indicating that customer relationship management has a positive relationship with customer satisfaction and customer satisfaction leads to customer loyalty. Also, the final results of this hypothesis showed that customer costs which are the first dimension from the first mediating variable have been rejected. This means it has no significant result. This negative result might be due to the strategies in these private gyms in Kuwait and might be because they give 
more attention to customer benefits above the customer costs.

This research targeted a sample from private gyms in Kuwait customers located in Kuwait City. The survey indicated that the majority of respondents were under the age of 20 with a percent of $16.8 \%$, a total of 140 respondents were between the age of 21 to 25 with a percent of $35 \%$, a total of 93 respondents were between the age of 26 to 30 with a percent of $23.3 \%$, a total of 42 respondents were between the age of 31 to 35 with a percent of $10.5 \%$, a total of 27 respondents were between the age of 36 to 40 with a percent of $6.8 \%$ and a total of 31 respondents were above 40 with a percent of $7.8 \%$, a total of 185 students with a percent of $46.3 \%$, a total of 209 employees with a percent of $52.3 \%$ and only an unemployed category of 6 respondents with a percent of $1.5 \%$, a total of 40 respondents with a percent of $10.0 \%$ from all the chosen private gyms in Kuwait for men, mixed and women and a total of 30 respondents that joined the gym before less than 3 months with a percent of $7.5 \%$, a total of 66 respondents joined the gym before less than 6 months with a percent of $16.5 \%$, a total of 58 respondents that joined the gym before less than one year with a percent of $14.5 \%$, a total of 55 respondents joined the gym between the last one to five years with a percent of $13.8 \%$, a total of 186 respondents joined the gym between the last five to ten years with a percent of $46.5 \%$ and only 5 respondents joined the gym before more than ten years with a percent of $1.3 \%$.

All of these investigations and outcomes of the study done by the demographic factors of respondents' characteristics such as age, gender, and occupation are required to develop customer relationship management in order to reach customer loyalty (Clemes et al., 2009). As long as Kuwaiti private gyms and their customers are using customer relationship management, these gyms should begin to explore new upgraded methodologies and the most suitable customer relationship management practices that mainly interact with the customer to get, keep and grow customers.
The structural model of the research tried to add a new concept to analyze the effect of all independent variables together on customer loyalty. Correlation between these variables was reasonably high and positive $R=0.790$ in table 14 and $R$ square of 0.624 . The overall value of f-ratio for independent variables was positive which means significant, but the t-test for all of them showed that trust variable was not significant and by support from the stepwise test, the modified model came up with a new change in it.

Based on that result, Kuwaiti private gyms should take into consideration the process of customer relationship management, integrated marketing communication, communications and relational bonds in order to reach customer loyalty. In addition, the gyms should educate the employees more about the importance of trust and its main effect on customer relationship management and customer loyalty. For the second alternative hypothesis result, which showed that there is a positive relationship between customer relationship management and customer loyalty through customer satisfaction as a mediating effect between them, they should pay a strong attention of customer satisfaction to the link between customer relationship management and customer loyalty.

In addition, the next recommendation that could enhance customer relationship management, and in turn customer satisfaction is to reach and increase customer loyalty. The Kuwaiti private gyms should have well implementation of customer relationship management between employees and customers. This system should be friendly and easy to use in the gyms and employees should always distribute to customers a feedback and their comments. As a marketing concept, the gyms should have one eye on the customer and another eye on the competitors to know any new important piece of information. Gyms should pay more attention to the customer values and how to deal with customers based on their wants and needs. Gyms should change their 
strategies about customer costs and try to come up with a new idea about it.

It is very important to know the customer needs and all of the private gyms in Kuwait should consider this point as the main strategy. They should always distribute feedbacks with comments to be updated with new information from the customers. In addition, they should focus more and more on using and developing the quality of customer relationship management, customer satisfaction to reach customer loyalty and to build a better competitive advantage in this sector. In addition, researchers called for more research on the enabling factors of applying electronic services such as Customer Relationship Management (CRM), Knowledge Management (KM) among others (e.g. Hunaiti et al., 2009; Shannak et al., 2010, 2012; Alkalha et al., 2012; Masa'deh et al., 2013a, b; Obeidat et al., 2017; Tarhini et al., 2017; Abualoush et al., 2018a, b; Aldalahmeh et al., 2018). The results of this research are particularly important from managerial and marketing perspectives more than the purely building of marketing strategies and campaigns focused on increasing profitability.

\section{References}

1. Alananzeh, O., Masa'deh, R., Jajwabreh, O., Al Mahmoud, A., \& Hamada, R. (2018). The Impact of Customer Relationship Management on Tourist Satisfaction: The Case of Radisson Resort in Aqaba City. Journal of Environmental Management and Tourism, 2(26), 227-240.

2. Abualoush, S., Bataineh, K., \& Alrowwad, A. (2018a). The Role of Knowledge Management Process and Intellectual Capital as Intermediary Variables between Knowledge Management Infrastructure and Organization Performance. Interdisciplinary Journal of Information, Knowledge, and Management, 13, 279-309.

3. Abualoush, S.H., Obeidat, A.M., Tarhini, A., \& Al-Badi, A. (2018b). The Role of Employees' Empowerment as an Intermediary Variable between Knowledge Management and Information Systems on
Employees' Performance. VINE Journal of Information and Knowledge Management Systems, 48(2), 217-237.

4. Al-dalahmeh, M., Masa'deh, R., Khalaf, R., \& Obeidat, B. (2018). The Effect of Employee Engagement on Organizational Performance via the Mediating Role of Job Satisfaction: The Case of IT Employees in Jordanian Banking Sector. Modern Applied Science, 12(6), 17-43.

5. Alkalha, Z., Al-Zu'bi, Z., Al-Dmour, H., \& Alshurideh, M. (2012). Investigating the Effects of Human Resource Policies on Organizational Performance: An Empirical Study on Commercial Banks Operating in Jordan. European Journal of Economics, Finance and Administrative Sciences, 51, 4464.

6. Al-Naser, R. (2016). The Mediating Effect of Employee Commitment on the Relationship between Soft Lean Practices and Service Quality of Private Jordanian Hospitals. Master Thesis, The University of Jordan, Jordan.

7. Alshurideh, M., Masa'deh, R., \& Alkurdi, B. (2012). The Effect of Customer Satisfaction upon Customer Retention in the Jordanian Mobile Market: An Empirical Investigation. European Journal of Economics, Finance and Administrative Sciences, 47, 69-78.

8. Amir, M., Yousof, H., \&Asma, E. (2014). The Effect of Using Customer Relationship Management System on Customer Loyalty. Case Study: Ansar Bank's Branches in East Azerbaijan. Indian J.Sci.Res, 8(1), 98-106.

9. Anderson, F., \& Lehmann, D. (1994). Customer Satisfaction, Market Share, and Profitability: Findings from Sweden. Journal of Marketing, 58(3), 53-66.

10.Ashour, L. (2006). Relationship Marketing as a Base for Achieving Customer Loyalty in the Jordanian Hotel Industry. Unpublished PhD Dissertation submitted to Graduate College of administrative and financial Studies, Amman Arab University for Graduate studies, Amman, Jordan. 
11.Aydin, S., Ozer, G., \& Arasil, O. (2005). Customer Loyalty and the Effect of Switching Costs as a Moderator Variable: A Case in the Turkish Mobile Phone Market. Marketing Intelligence and Planning, 23(1), 89-103.

12.Bashir, N. (2017). Impact of Customer Relationship Management on Customer Retention: A Case of Private Banks of Sialkot, Punjab. International Journal of Science and Technology Research, 6(8), 293302.

13.Bose, R. (2002). Customer Relationship Management: Key Components for IT Success. Industrial Management \& Data Systems, 102(2), 89-97.

14.Boulding, W., Staelin, R., Ehret, M., \& Johnston, W. J. (2005). A Customer Relationship Management Roadmap: What is Known, Potential Pitfalls, and where to Go. Journal of Marketing, 69(4), 155-166.

15.Chan, L., Hui, Y., Lo, H., Tse, S., Tso, G., \& $\mathrm{Wu}, \mathrm{M}$. (2003). Consumer Satisfaction Index: New Practice and Findings. European Journal of Marketing, 37(5/6).

16.Chikweche, T., \& Fletcher, R. (2013). Customer Relationship Management at the Base of the Pyramid: Myth or Reality? Journal of Consumer Marketing, 30(3), 295309.

17.Choi, T.Y., \& Chu, R. (2000).Determinants of Hotel Guests' Satisfaction and Repeat Patronage in the Hong Kong Hotel Industry. Hospitality Management, 20(3), 277-297.

18. Christodoulides, G., \& Michaelidou, N. (2011). Shopping Motives as Antecedents of E-Satisfaction and E-Loyalty. Journal of Marketing Management, 27(1-2), 181-197.

19.Cia World Factbook. (2017). Kuwait Economy 2017. Retrieved from: https://theodora.com/wfbcurrent/kuwait /kuwait_economy.html

20.Clemes, M., Wu, J., Hu, B-D., \&Gan, C. (2009). An Empirical Study of Behavioral
Intentions in the Taiwan Hotel Industry. Innovative Marketing, 5(3), 30-50.

21.Fathi, S., Rezaei, Z., \& Ranjbarian, B. (2012). Factors Influencing on Customer's E-Satisfaction: A Case Study from Iran. Interdisciplinary Journal of Contemporary Research in Business, 3(9), 1496-1509.

22.Finnegan, D.J., \& Currie, W.L. (2010). A Multi-Layered Approach to CRM Implementation: An Integration Perspective. European Management Journal, 28(2), 153- 167.

23. Fisher, A. (2001). Winning the Battle for Customers. Journal of Financial Services Marketing, 6(2), 77-83.

24.Fozia, R., \& Shiamwama, S. (2014). Impact of Customer Relationship Management as a Strategy for Competitive Advantage in Kenyan Public Universities: A Case Study of Moi University. International Journal of Business, Humanities and Technology, 4(4), 136-144.

25.Geyskens, I., Steenkamp, J-B., Scheer, L., \& Kumar, N. (1996). An Investigation into the Joint Effects of Trust and Dependence on Relationship Commitment: A Transatlantic Study. International Journal of Research in Marketing, 13, 303-317.

26.Hair, J., Black, W.C., Babin, B.J., \& Anderson, R.E. (2010). Multivariate Data Analysis: A Global Perspective, 7th edition, Pearson Prentice-Hall, NJ.

27.Hill, N., \& Alexander, J. (2006). The Handbook of Customer Satisfaction and Loyalty Measurement, Gower Publishing.

28.Huffmire, D. (2001). Improving Customer Satisfaction, Loyalty, and Profit: An Integrated Measurement and Management System. Choice, 38(5), 946947.

29.Hunaiti, Z., Mansour, M., \& Al-Nawafleh, A. (2009). Electronic Commerce Adoption Barriers in Small and Medium-Sized Enterprises (SMEs) in Developing Countries: The Case of Libya. Innovation and Knowledge Management in Twin Track 
Economies Challenges and SolutionsProceedings of the 11th International Business Information Management Association Conference, IBIMA 2009, 1-3, 1375-1383.

30.Javadein, S.R., Khanlari, A. \& Estiri, M. (2008). Customer Loyalty in the Sport Services Industry: The Role of Service Quality, Customer Satisfaction, Commitment and Trust. International Journal of Human Sciences, 5(2).

31.Kerr, G., Schultz, D., Patti, C., \& Kim, I. (2008). An Inside-out Approach to Integrated Marketing Communication: An International Analysis. J. Advertising, 27(4), 511-548.

32.Khawaja, R. (2016). The Impact of Electronic Customer Relationship Management (ECRM) Practices in Business Performance of Jordanian Commercial Banks. MBA thesis, The University of Jordan, Jordan.

33.Kocoglu, D., \& Kirmaci, S. (2012). Customer Relationship Management and Customer Loyalty: A Survey in the Sector of Banking. International Journal of Business and Social Science, 3(3), 282-291.

34.Kotler, P., \& Keller, K. (2016). Marketing Management Book, 15th edition. United States of America: Pearson Education, Inc.

35.Kuwait Gyms. (2017). Find Your Perfect Gym. Retrieved From: http://kuwaitgyms.com

36.Long, C., Khalafinezhad, R., Ismail, W., \& Rasid, S. (2013). Impact of CRM Factors on Customer Satisfaction and Loyalty. Asian Social Science, 9(10), 247-252.

37.Lovelock, C., \& Wirts, J. (2017). Services Marketing Book: People, Technology, Strategy, 8th edition, United States of America: Pearson Education, Inc.

38.Ltifi, M., \& Jamel-Eddine, G. (2012). ESatisfaction and E-Loyalty of Customers Shopping Online. Journal of Internet Banking and Commerce, 17(1), 1-17.
39.Malik, G. (2015). Impact of Customer Relationship Management on Customer Loyalty and Customer Retention with reference to Automobile Sector. University Journal of Research, 01(01), 70-83.

40.Masa'deh, R., Gharaibeh, A., Maqableh, M., \& Karajeh, H. (2013a). An Empirical Study of Antecedents and Outcomes of Knowledge Sharing Capability in Jordanian Telecommunication Firms: A Structural Equation Modeling Approach. Life Science Journal, 10 (4), 2284-2296.

41.Masa'deh, R., Shannak, R., \& Maqableh, M. (2013b). A Structural Equation Modeling Approach for Determining Antecedents and Outcomes of Students' Attitude toward Mobile Commerce Adoption. Life Science Journal, 10 (4), 23212333

42.Mohite, R., Kanthe, R., \& Pawar, V. (2013). Customer Relationship Management in Hospitals with Reference to Miraj City. International Journal of Business Management and Research, 3(1), 131-183.

43.Mustafa, E.(2011). Determinants of ECommerce Customer Satisfaction, Trust, and Loyalty in Saudi Arabia. Journal of Electronic Commerce Research, 12(1), 7893.

44.Nazir, S., Khan, S., Jamil, R., \& Mehmood, Q. (2014). Impact of Customer Relationship Management on Customer Satisfaction in Hoteling Industry. Journal of Management Info, 3(1), 84-96.

45.Obeidat, B., Tarhini, A., \& Aqqad, N. (2017). The Impact of Intellectual Capital on Innovation via the Mediating Role of Knowledge Management: A Structural Equation Modeling Approach. International Journal of Knowledge Management Studies, 8 (3-4), 273-298.

46.Oliver, R.L. (1997). Satisfaction: A Behavioral Perspective on the Consumer. New York: The McGraw-Hill Companies Inc.

47.Oliver, R.L., Rust, R.T., \& Varki, S. (1997). Customer Delight: Foundations, Findings,

Ra'ed MASA'DEH, Hassan Khalid HAYAT and Hani AL-DMOUR (2019), IBIMA Business Review, DOI: $10.5171 / 2019.815930$ 
and Managerial, Insight. Journal of Retailing, 73(3), 311-336.

48.Piercy, N., \& Rich, N. (2009). High Quality and Low Cost: The Lean Service Centre. European Journal of Marketing, 43(11/12), 1477-1497.

49.Rahim, A.G. (2017). Customer Satisfaction and Loyalty: A Study of Interrelationship and Effects in Nigerian domestic Airline Industry. Oradea Journal of Business and Economics, II(1), 7-20.

50.Rehman, A., Akhtar, N., \& Hafeez, I. (2014). Factors Affecting Customer Satisfaction in Banking Sector of Pakistan. International Review of Management and Business Research, 3(2), 1014-1025.

51.Roberts, M., Hsiao, W., Berman, P., \& Reich, M. (2003). Getting Health Reform Right: A Guide to Improving Performance and Equity. Oxford University Press, Oxford, U.K.

52.Rust, A., Venus, D., \& Ebrahimi, A. (2012).Marketing Management: The Study and Development Center of Humanities Books of University (Samt), Edition XVI.

53.Schultz, D. (2003). Determine Outcomes First to Measure Efforts. Marketing News, $37(18)$.

54.Schultz, D., \& Schultz, H. (2003). IMC The Next Generation: Five Steps for Delivering Value and Measuring Returns using Marketing Communication. New York: McGraw-Hill.

55.Sekaran, U., \& Bougie, R. (2016). Research Methods for Business Book: A Skill-Building Approach, 7th edition, United Kingdom: John Wiley \& Sons.

56.Shannak, R., Al-Zu'bi, Z., Obeidat, B., Alshurideh, M., \& Altamony, H. (2012). A Theoretical Perspective on the Relationship between Knowledge
Management Systems, Customer Knowledge Management, and Firm Competitive Advantage. European Journal of Social Sciences, 32 (4), 520-532.

57.Shannak, R., Obeidat, B., \& Almajali, D. (2010). Information Technology Investments: A Literature Review. Business Transformation through Innovation and Knowledge Management: An Academic Perspective-Proceedings of the 14th International Business Information Management Association Conference, IBIMA 2010, 1356-1368.

58.Suwono, L., \&Sihombing, S. (2016). Factors Affecting Customer Loyalty of Fitness Centers: An Empirical Study. Journal DinamikaManajemen, 7(1), 45-55.

59.Tabachnick, B.G., \& Fidell, L.S. (2001). Using Multivariate Statistics, 4th edition. NewYork: Harper Collins.

60.Tarhini, A., Al-Busaidi, K., Bany Mohammed, A., \& Maqableh, M. (2017). Factors Influencing Students' Adoption of E-Learning: A Structural Equation Modeling Approach. Journal of International Education in Business, 10(2), 164-182.

61.Thorson, E., \& Moore, J. (1996). Integrated Communication: Synergy of Persuasive Voices. New Jersey: Lawrence Erlbaum.

62.Too, H.Y., Souchon, A.L., \& Thirkell, P.C. (2001). Relationship Marketing and Customer Loyalty in a Retail Setting: A Dyadic Exploration. Journal of Marketing Management, 17(1), 89-93.

63.Zins, A. (2001). Relative Attitudes and Commitment in Customer Loyalty Models: Some Experiences in the Commercial Airline Industry. International Journal of Service Industry Management, 12(3), 269294. 